\title{
UV irradiation and micro filtration effects on micro particle development and microbial water quality in recirculation aquaculture systems
}

de Jesus Gregersen, Joao; Pedersen, Per Bovbjerg; Pedersen, Lars-Flemming; Liu, Dibo; Dalsgaard, Anne Johanne Tang

\section{Published in:}

Aquaculture

Link to article, DOI:

10.1016/j.aquaculture.2019.734785

Publication date:

2020

Document Version

Peer reviewed version

Link back to DTU Orbit

Citation (APA):

de Jesus Gregersen, J., Pedersen, P. B., Pedersen, L-F., Liu, D., \& Dalsgaard, A. J. T. (2020). UV irradiation and micro filtration effects on micro particle development and microbial water quality in recirculation aquaculture systems. Aquaculture, [734785]. https://doi.org/10.1016/j.aquaculture.2019.734785

\section{General rights}

Copyright and moral rights for the publications made accessible in the public portal are retained by the authors and/or other copyright owners and it is a condition of accessing publications that users recognise and abide by the legal requirements associated with these rights.

- Users may download and print one copy of any publication from the public portal for the purpose of private study or research.

- You may not further distribute the material or use it for any profit-making activity or commercial gain

- You may freely distribute the URL identifying the publication in the public portal 


\section{Journal Pre-proof}

UV irradiation and micro filtration effects on micro particle development and microbial water quality in recirculation aquaculture systems

Kim João de Jesus Gregersen, Per Bovbjerg Pedersen, LarsFlemming Pedersen, Dibo Liu, Johanne Dalsgaard

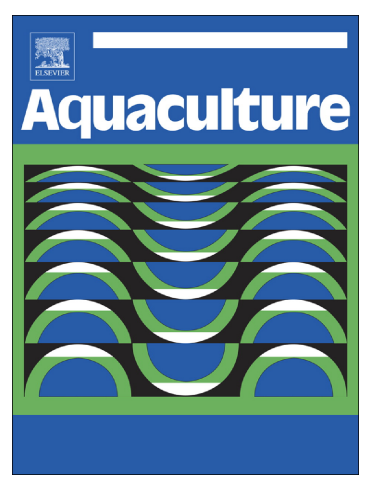

PII: S0044-8486(19)32185-4

DOI: https://doi.org/10.1016/j.aquaculture.2019.734785

Reference: AQUA 734785

To appear in: aquaculture

Received date: 21 August 2019

Revised date: 25 November 2019

Accepted date: 26 November 2019

Please cite this article as: K.J. de Jesus Gregersen, P.B. Pedersen, L.-F. Pedersen, et al., UV irradiation and micro filtration effects on micro particle development and microbial water quality in recirculation aquaculture systems, aquaculture (2019), https://doi.org/10.1016/ j.aquaculture.2019.734785

This is a PDF file of an article that has undergone enhancements after acceptance, such as the addition of a cover page and metadata, and formatting for readability, but it is not yet the definitive version of record. This version will undergo additional copyediting, typesetting and review before it is published in its final form, but we are providing this version to give early visibility of the article. Please note that, during the production process, errors may be discovered which could affect the content, and all legal disclaimers that apply to the journal pertain.

(C) 2019 Published by Elsevier. 
UV irradiation and micro filtration effects on micro particle development and microbial water quality in recirculation aquaculture systems

Authors:

Kim João de Jesus Gregersen

Corresponding author.

Affiliation: Technical University of Denmark, DTU Aqua, Section for Aquaculture, The North Sea Research Centre, P.O. Box 101, DK-9850 Hirtshals, Denmark

jdjg@aqua.dtu.dk

Per Bovbjerg Pedersen

Affiliation: Technical University of Denmark, DTU Aqua, Section for Aquacult re, 1 le North Sea Research Centre, P.O. Box 101, DK-9850 Hirtshals, Denmark

pbp@aqua.dtu.dk

Lars-Flemming Pedersen

Affiliation: Technical University of Denmark, DTU Aqua, Sectir $n+$ jr Aquaculture, The North Sea Research Centre, P.O. Box 101, DK-9850 Hirtshals, Denmark

lfp@aqua.dtu.dk

Dibo Liu

Affiliation: Technical University of Denmark, DT J ıq ^d, Section for Aquaculture, The North Sea Research Centre, P.O. Box 101, DK-9850 Hirtshals, Denmark*

liu@igb-berlin.de

*Permanent address: Leibniz-Institute of Freshwater Ec 'ngy and Inland Fisheries, Mueggelseedamm 301, 12587 Berlin, Germany

Johanne Dalsgaard

Affiliation: Technical University of D nmark, DTU Aqua, Section for Aquaculture, The North Sea Research Centre, P.O. Box 101, DK-9850 Hirtshals, Denmark

jtd@aqua.dtu.dk

Corresponding author contact information:

Email: jdjg@aqua.dtu.dk

Phone number: 004526228441

Address: DTU Aqua, Niels Juelsvej 30, 9850 Hirtshals, Denmark. 


\begin{abstract}
Recent studies have focused on micro particle build-up in recirculation aquaculture systems (RAS), and a correlation between micro particles and microbial activity has been shown. This study evaluated how micro particle build-up and microbial activity are affected by UV irradiation and micro filtration. Using 12 identical pilot scale RAS stocked with rainbow trout (Oncorhynchus mykiss), a two-factor factorial experiment was carried out testing in triplicate systems the effect of UV irradiation (systems with or without) in combination with cartridge filtration ( 1 or $200 \mu \mathrm{m}$ pore size) on selected water quality parameters. The trial ran for 13 weeks. Water samples were obtained once a week, and the number and size distribution of micro particles was analysed. Microbial activity was derived from the hydrogen peroxide degradation rate, and concentrations of total and dissolved organic matter were measured as chemical oxygen demand (COD).

Overall, both UV and cartridge filtration had significant effect $(<0.05)$ on micro particle distribution and microbial activity in the systems. By the end of the trial, a two-way Anova showed that UV treated RAS, independently of cartridge filtration pore size, were significantly $(\mathrm{p}<0.05)$ lower in micro particle numbers $(74 \%$ reduc: ;n), micro particle surface area $(54 \%$ reduction), and dissolved COD (34\% reduction) compared to systems without I IV. : imilarly, microbial activity was reduced up to $89 \%$ independently of cartridge filtration. UV thus appeared to reduce nic s particle numbers by destroying bacteria. In addition, the effect of UV on dissolved COD suggested a possible fe-lbacn mechanism between microbial activity and substrate release in the systems. For micro filtration, a 1 vs. $200 \mu \mathrm{r}$, po e size significantly reduced the number of micro particles (by 50\%), micro particle volume (by 83\%), and micro particle su tace area (by 73\%) independently of UV treatment. This was accompanied by a significant reduction in particule e - DD (80\%) and microbial activity (approximately 54\% reduction independent of the use of UV). Hence, cartridge filtr ttion appeared to reduce a build-up of micro particle by directly removing bacteria and bacteria substrate. In conclusi in th a study sustains that combining UV and particle removal is a potential viable tool for managing microbial water quality 1. $_{\text {. }}$ AS.
\end{abstract}




\section{Introduction}

Recent studies on micro particles in recirculating aquaculture systems (RAS) have focused on the build-up of micro particles in RAS and the correlation with microbial water quality (Becke et al., 2018; de Jesus Gregersen et al., 2018; Pedersen et al., 2017; Fernandes et al., 2016). Increasing recirculation intensity increases the level of micro particles (Patterson et al., 1999), and micro particles below $20 \mu \mathrm{m}$ may account for more than $90 \%$ of all particles in some systems (Fernandes et al., 2014).

In RAS, micro particles are generated from organic waste including fish faeces and feed spill, and from biofilm released from surfaces and biofilters. Bacteria are closely linked to these micro particles and may even constitute the micro particle itself. It is generally believed that micro particles are unwanted but the full implication of micro particles in RAS is still not well understood. Pedersen et al. (2017) described a strong, positive correlation between micro particle levels and microbial activity in semi-intensive RAS, suggesting that microbial activity is controlled by micro particle availability in such systems. Lu et al. ( 2018) studied the expression of different genes associated with immune response in rainbow trout (Oncorhynchus mykiss) and zebrafish (Danio rerio) when exposed to inert styrofoam particles ranging from $U_{.}{ }^{\text {to }} 90 \mu \mathrm{m}$ in diameter. They found that smaller particles were more likely to build up in the gills and caused changes in gene expression. On the other hand, Becke et al. (2018) found no adverse effects of suspended solids on the growth of $\mathrm{r}: \mathrm{nb} \mathrm{v}$ trout exposed to high levels of suspended solids in an 18 week RAS exposure trial.

To reduce the load of particulate organic matter and, consequently rea ce microbial activity, a few strategies of either removing particles or avoiding their formation in the first place have aen tested. Feed binders show good potential for increasing faecal stability, supposedly making them easier to em se and thereby reduce the formation of micro particles (Brinker, 2007). However, positive effects on water quality ( $\mathrm{f}^{\prime}$ ysical, chemical, or biological changes) in RAS by adding feed binders have not yet been demonstrated. Another appre ch $i$ volved adding floating material to the fish feed in order to create floating faeces (Unger and Brinker, 2013). When floating : $^{\circ}$ ces where tested in an experimental RAS, drum filters removal efficiency was twice as high in systems fed the experiı. - nntal diet compared to a commercial control diet, however the impacts on water quality were less obvious (Schumann et $\left.c^{\prime} . .20, l\right)$.

Alternatively to modifying the feed, it may he pu sible to reduce the build of particle by UV irradiation or micro particle filtration. A fraction of micro particles in $\Gamma$ IS is composed of free swimming bacteria (Franco-Nava et al., 2004; Sharrer et $a l ., 2005)$, and the use of UV irradiation sho' ' $d$ reduce the total number of micro particles in the water by controlling bacteria development. UV irradiation degrad s iciubial DNA stopping bacteria from multiplying while having no direct impact on non-living / inert particles and dis. $1 v$ d srganic matter (Timmons and Ebeling, 2010). While the use of UV irradiation can be expensive, it is a mature technology w dely used in RAS and its application is fairly straight forward (Summerfelt, 2003). Few, if any studies have demonstrated the impact of UV irradiation on microbial water quality dynamics in RAS. A recent study by Huyben et al. (2018) looked in to the application of UV and membrane filtration in a pilot scale RAS as a means to control bacterial load. The results obtained indicate that both technologies were capable of reducing heterotrophic bacteria by over 98\% in a single pass set up, however, long term implications on the water quality were not studied.

Water quality effects of removing micro particles e.g. by microscreens or membrane filters have been widely studied. Fernandes et al. (2014) demonstrated significant differences in particulate parameters in RAS with and without microscreens $(100,60$ and $20 \mu \mathrm{m})$. Albeit the time to reach equilibrium seemingly increased with increasing mesh size, particle numbers, particles surface area or particle volume in the three microscreen groups (100, 60 and $20 \mu \mathrm{m})$ did not significantly differ at the end of the trial. Using ultrafiltration, Wold et al. (2014) obtained a large reduction of micro particles in a cod larvae (Gadus morhua) RAS, as well as a significant reduction in the number of bacteria. However, application of this type of filtration to full scale RAS is considered complicated and costly (Viadero and Noblet, 2002; Wu et al., 2008). 
The objective of the currents study was to evaluate the extent to which micro particles and microbial activity in RAS could be controlled by the individual and / or combined use of UV irradiation and micro filtration. To this purpose a two-factor factorial experiment was carried out testing pilot scale RAS with or without UV irradiation and with two levels of micro filtration $(1 \mu \mathrm{m}$ and $200 \mu \mathrm{m})$.

\section{Materials and methods}

\subsection{Experimental setup}

The trial was conducted in twelve identical $1.7 \mathrm{~m}^{3}$ pilot scale RAS (fig. 1). Each RAS consisted of a 5001 rearing tank, a swirl separator, a 3001 pump sump, a 8001 submerged fixed bed biofilter, and a trickling filter. The fixed bed biofilter and trickling filter were filled with BIO-BLOK $150^{\circledR}$ elements (Expo-net, Hjørring, Denmark). An Aqua Medic Ocean Runner 6500 (Aqua Medic, Bissendorf, Germany) pump provided the flow in to the biofilter. After the trickling filter, a flow of $15001 \mathrm{~h}^{-1}$ was diverted in to the rearing thanks, while the remaining water overflowed back in to he pump sump, resulting in a hydraulic retention time (HRT) of approximately 20 minutes in the rearing tanks.

All systems where fitted with a cartridge filter housing treating a side stream of th` pump sump flow. Six RAS were fitted with a 10 " filter housing and a $1 \mu \mathrm{m}$ cartridge filter (Ultra-Depth PP-TF $00 \mu \mathrm{m} 10$ " DOE, Ultrafilter Skandinavien ApS, Denmark), while the other six RAS were fitted with an 10" filter hou sing and a $200 \mu \mathrm{m}$ cartridge filter (Ultra-Pure Sleeve Nylon $200 \mu \mathrm{m}$ 10", Ultrafilter Skandinavien ApS, Denmark). The $200 \mu_{\text {. }}$ c cartridge filters were chosen to mimic commercial RAS conditions where drum filters are typically applied to remo e l r re particles. Three of the RAS units fitted with either a 1 $\mu \mathrm{m}$ or a $200 \mu \mathrm{m}$ cartridge filter were also fitted with a $75 \mathrm{~W}$ I / V iner (Pond filter, China) placed in series after the cartridge filter. The combination of cartridge and UV filters esul ed in four treatment groups in triplicate randomly distributed throughout the 12 RAS: $1 \mu \mathrm{m}$ cartridge filter with UV $(1 \mu \eta+\mathrm{UV}), 200 \mu \mathrm{m}$ cartridge filter with UV $(200 \mu \mathrm{m}+\mathrm{UV}), 1 \mu \mathrm{m}$ cartridge filter without UV $(1 \mu \mathrm{m} \div \mathrm{UV})$, and $200 \mu \mathrm{m} 、$ rtridge filter without UV $(200 \mu \mathrm{m} \div \mathrm{UV})$. Water was pumped through the cartridge filter and UV filter using a $2200 \mathrm{l} \mathrm{h}^{-1}, \mathrm{u} \mathrm{n} \mathrm{F}$, Selekta 350W, Harald Nyborg, Denmark).

All systems were in operation prior to the tria 1 an $^{\top}$ biofilters were therefore already activated. At start up, all systems were emptied, tanks cleaned, and fresh tap water vas alded in order to follow the temporal development in different water quality parameters. Each system was stocked with $? .5 \pm 0.1 \mathrm{~kg}$ juvenile rainbow trout receiving $250 \mathrm{~g}$ feed day ${ }^{-1}$ (Efico, Biomar, Denmark) fed during 12 hours using a. ' n mauc belt feeders. A daily water exchange (make-up water, MUW) of 801 day $^{-1}$ was applied, resulting in a feed loadin between 7.2 and 7.5. Any dead fish $\mathrm{v}$ are removed daily and their weight noted. Swirl separators were emptied each morning and any feed spill recorded and enumerated.

The trial ran for 13 weeks and grab samples of the water in each of the 12 RAS were collected once a week. Cartridge filters and UV filter units were started after the first set of water samples were obtained, representing "system specific" time zero samples unaffected by treatments. During the first 6 weeks of the trial, all cartridge filters were swapped and cleaned once a day. However, as systems developed it became necessary to increase the capacity of the microfilters, increasing the filter housing from 10" to 20" (Ultra-Depth PP-TF 1,00 $\mu \mathrm{m}$ 20" DOE, Ultrafilter Skandinavien ApS, Denmark) while maintaining cartridge filter mesh size at 1 and $200 \mu \mathrm{m}$. Furthermore, the daily cleaning routine was increased from one to three times a day in systems fitted with $1 \mu \mathrm{m}$ cartridge filters to ensure a proper water flow through the filters. The serial placement of the UV lamp after the mechanical cartridge filters was made to better simulate a typical RAS set up. However, after a few weeks, clogging of the filters caused the water flow also to the UVs to be reduced, which was reflected by in the results (larger fluctuations) experienced during weeks 5 and 6. 


\subsection{Water sampling and analysis}

Water sampling started two days after fish were added to the systems to avoid particulate matter re-suspension related to the handling of fish. Grab samples were collected at the top of the swirl separators as indicated in figure 1. A 51 sample was collected in each RAS and spilt into homogeneous subsamples for individual analysis. Temperature, oxygen, and $\mathrm{pH}$ were measured in the swirl separators in the morning before daily routines using a Hach HQ40d Portable Multi Meter (Hach Lange, Germany).

Micro particle numbers and size distribution were measured using an AccuSizer 780 SIS (Particle Sizing Systems, Santa Barbara, CA, USA) for particles between 10 and $200 \mu \mathrm{m}$ following the procedure described in Fernandes et al. (2014). Furthermore, particles between 1 and $30 \mu \mathrm{m}$ were measured using a Multisizer 4e Coulter Counter (Bechman Coulter, Inc, Indianapolis, USA). Results from the two measurements were subsequently combined to give a complete particle size distribution in the size range 1-200 $\mu \mathrm{m}$ as explained and verified by de Jesus Gregersu ' et al. (2018).

Particles were grouped in size classes as described in Patterson et al. (1999). Vol 'me ( V; $\mathrm{mm}^{3} \mathrm{ml}^{-1}$ ) and surface area (SA; $\mathrm{mm}^{2}$ $\mathrm{ml}^{-1}$ ) of particles within each size class was calculated (assuming spherical $\operatorname{artı}{ }^{\prime} \mathrm{es}$ ) using the equations: $\mathrm{V}=4 / 3 \pi \mathrm{r}^{3} \mathrm{x}$, and $\mathrm{SA}=4 \pi \mathrm{r}^{2} \mathrm{x}$, where $\mathrm{V}$ is the total volume of particles in a specific size cl- $\mathrm{s}, \mathrm{S} \mathrm{n}$ is the total surface area of the same particles, $\mathrm{r}$ is particle radius within the size class, and $\mathrm{x}$ is the number of particle wi in that size class. The total particle numbers (PN), the total particle volume (PV), and the total particle surface area (PSA' th the full range measured (1-200 $\mu \mathrm{m})$ was calculated by summing the contribution from the different size classes.

To compare systems, particle size distributions were summ^ izeu uy the $\beta$ value conceived by Patterson et al. (1999) and further described by Fernandes et al. (2014). In short, $t^{\prime}$ e $\beta$ /alue is the slope of the log-log transformed relationship between the number of particles within size classes and the corre $_{1}$ ' 'nding size class medians. A lower $\beta$ value indicates a system dominated by larger particles whereas a higher $\beta$ value : ndicates a system dominated by smaller particles.

Microbial activity was quantified using the hydi g $n$ peroxide $\left(\mathrm{H}_{2} \mathrm{O}_{2}\right)$ decomposition rate assay with the degradation rate constant $\left(\mathrm{k}_{\mathrm{la}}, \mathrm{h}^{-1}\right)$ used to quantify the microbi $\mathrm{l}$ a ${ }^{-}$ivity (Pedersen et al., 2019). This method estimates the "rate of microbial activity" based on the degradation of $\mathrm{H}_{2} \mathrm{O}_{2}$. " he tauter the degradation of $\mathrm{H}_{2} \mathrm{O}_{2}$, the higher the microbial activity.

Nitrate-N and chemical oxygen demand (C,D) concentrations were measured spectrophotometrically following ISO 7890-1 (1986) and ISO 6060 (1989), respect $\sim^{\prime} \mathrm{v}$. ine chemical oxygen demand was measured in non-filtered (COD

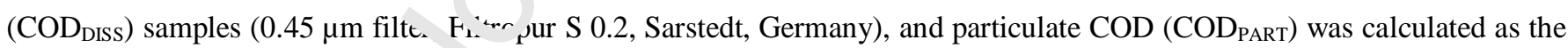
difference between the two.

All samples were collected and analysed in duplicate.

\subsection{Data analysis}

All data were transformed into moving averages of three succeeding sampling points (e.g. data from week one corresponds to the average of the data collected at time 0,1 and 2). Statistical analyses were performed in SigmaPlot 13.0 (Systat software Inc., USA). Results of the two main factors (UV irradiation and cartridge filtration) were compared by the end of the trial (on average values of weeks 11, 12 and 13) using two way ANOVA followed by a Holm-Sidak test in case of significant differences. In addition, Pearson Product Moment correlation analyses were carried out to test for correlation between volume of particles and $\mathrm{COD}_{\mathrm{PART}}$, $\mathrm{COD}_{\mathrm{DISS}}$ and microbial activity, $\mathrm{COD}_{\mathrm{TOTAL}}$ and microbial activity, and number of particles and microbial activity. Differences were considered significant at $p<0.05$.

All data are presented as average \pm standard deviation unless otherwise stated. 


\section{Results}

There was no cooling of the systems and the temperature therefore fluctuated between a minimum of $15.8 \pm 0.5{ }^{\circ} \mathrm{C}$ to a maximum of $21.3 \pm 0.5^{\circ} \mathrm{C}$. Fish mortality ranged between 0.1 and 0.3 fish day ${ }^{-1}$ with no significant difference between systems or treatments. Oxygen saturation fluctuated between 75 and 105\%, pH fluctuated between 7.1 and 7.5 , and nitrate- $\mathrm{N}$ ranged between 91.5 and $98.2 \mathrm{mg} \mathrm{l}^{-1}$ at the end of the trial independent of treatment groups $(\mathrm{p}>0.05)$.

\subsection{Microparticles}

\subsubsection{Particle numbers}

The number of micro particles increased immediately after start in the $200 \mu \mathrm{m} \div \mathrm{UV}$ treatment systems and stabilized after approximately 5 weeks of operation at about 3 million particles $\mathrm{ml}^{-1}$ (fig. 2a). In comparison, the other treatment groups remained low for the first 7 weeks before starting to diverge. The $1 \mu \mathrm{m} \div \mathrm{UV}$ tre, ment group increased to approximately 2 million particles $\mathrm{ml}^{-1}$ by week 10 , while the $200 \mu \mathrm{m}+\mathrm{UV}$ and the $1 \mu \mathrm{m}+\mathrm{U} \quad \mathrm{r} \mathrm{c}_{\iota}$ hed $<0.5$ and 1 million particles ml ${ }^{-1}$, respectively, after 12 weeks. By the end of the trial, both UV and cartridge f ${ }^{\prime}$-atlun were found to affected particle numbers. Systems with UV treatment had significantly less particles than systems $v$ ith $\cdots t$ JV irradiation and systems fitted with $1 \mu \mathrm{m}$ cartridge filters had significantly less particles than systems using 200 .... arı idge filters (table 1).

\subsubsection{Particle volume}

Particle volume in systems fitted with $200 \mu \mathrm{m}$ cartridge filtel s su . $_{1}$ ly increased about 3 weeks into the study and ended at $0.04 \pm 0.01$ and $0.05 \pm 0.01 \mathrm{~mm}^{3} \mathrm{ml}^{-1}$, respectively in th $\div 2() \mu \mathrm{m}+\mathrm{UV}$ and $200 \mu \mathrm{m} \div \mathrm{UV}$ treatment systems (fig. 2b). Particle volume in systems with $1 \mu \mathrm{m}$ cartridge filters transiently . sreased in week 3-6 presumably due to limited filtration capacity (section 2.1). After adjusting filtration capacity, partı' ${ }^{\prime}$. volume decreased and stabilized at $0.007 \pm 0.002$ and $0.009 \pm 0.001$ $\mathrm{mm}^{3} \mathrm{ml}^{-1}$, respectively in the $1 \mu \mathrm{m}+\mathrm{UV}$ and $1, \mathrm{~m} \div \mathrm{VV}$ systems. By the end of the trial, cartridge filtration had reduced particle volume significantly, being much low er \&. systems fitted with 1 vs. $200 \mu \mathrm{m}$ cartridge filters. UV irradiation on the other hand had no significant effect on parti - e vor ime (table 1).

\subsubsection{Particle surface area}

Particle surface area mirrored, to . $m_{\iota}$. ev ent, the development in particle volume (fig. 2c). Treatment $200 \mu \mathrm{m} \div \mathrm{UV}$ increased immediately after start and reached $382 \pm 4.8 \mathrm{~mm}^{2} \mathrm{ml}^{-1}$ at the end of the trial. In the $200 \mu \mathrm{m}+\mathrm{UV}$ group the increase were less pronounced and PSA ended at $23.5 \pm 5.2 \mathrm{~mm}^{2} \mathrm{ml}^{-1}$. In the $1 \mu \mathrm{m} \div \mathrm{UV}$ group, PSA ended at $13.7 \pm 2.8 \mathrm{~mm}^{2} \mathrm{ml}^{-1}$ while seemingly no increase in PSA occurred in the $1 \mu \mathrm{m}+\mathrm{UV}$ treatment group despite a transient increase due to limited filtration capacity halfway through the trial. A two-way Anova by the end of trial showed that both treatment factors affected PSA significantly and independently of each other, i.e., UV vs. no UV treatment and $1 \mu \mathrm{m}$ vs. $200 \mu \mathrm{m}$ cartridge filtration both reduced PSA in the systems (table 1 ).

\subsection{3. $\beta$ values}

Particle size distributions were significantly affected by the use of UV, whereas cartridge filtration size had no effect on the distribution (table 1). Hence, $\beta$ values in systems with UV were significantly lower $(3.71 \pm 0.12$ and $3.77 \pm 0.08$, respectively, for $1 \mu \mathrm{m}+\mathrm{UV}$ and $200 \mu \mathrm{m}+\mathrm{UV}$ systems $)$ than $\beta$ values in systems without UV treatment $(3.87 \pm 0.10$ and $3.86 \pm 0.10$, respectively, for $1 \mu \mathrm{m} \div \mathrm{UV}$ and $200 \mu \mathrm{m} \div \mathrm{UV}$ systems). 


\subsection{Microbial activity}

Microbial activity was the only metric where there was significant interaction between UV treatment and cartridge filtration (table 1 and fig. 2d). While this interaction prevents any conclusions about main effects, the use of ultraviolet irradiation kept microbial activity low throughout the trial, except for a transient increase while the $1 \mu \mathrm{m}$ filters were under-dimensioned, irrespective of filtration. Hence, microbial activity in UV treated systems was by the end of the trial very similar to the activity at the start of the trial (averaging $0.04 \pm 0.02$ vs. $0.03 \pm 0.001 \mathrm{~h}^{-1}$, respectively). In systems without UV irradiation, $1 \mu \mathrm{m}$ cartridge filters reduced microbial activity by approximately $50 \%$ compared to systems with $200 \mu \mathrm{m}$ cartridge filters $(0.25 \pm$ 0.07 vs. $0.52 \pm 0.1 \mathrm{~h}^{-1}$, respectively). Comparing systems with either 1 or $200 \mu \mathrm{m}$ cartridge filters, UV filtration significantly lowered microbial activity.

Microbial activity was highly correlated with particle numbers in all treatment systems (correlation coefficients (r) ranging between 0.87 and 0.95 ; table 2), as well as with COD DISs ( $\mathrm{r}$ ranging between 0.61 and 0.81 ; table 2 ) and $\mathrm{COD}_{\text {TOTAL }}(\mathrm{r}$ ranging between 0.65 and 0.83 ; table 2 )

\subsection{COD}

Dissolved COD increased significantly slower in systems with UV compa. ad to systems without (fig. 2e). Cartridge filtration had no impact on COD Diss build-up, and there was no interaction retwe in the two main treatment factors (table 1). All treatments, except $1 \mu \mathrm{m}+\mathrm{UV}$, seemed to be still increasing by the er $\mathrm{d}$ or he trial. At this point, CODDiss in $1 \mu \mathrm{m}+\mathrm{UV}$ and $200 \mu \mathrm{m}+\mathrm{UV}$ treated systems amounted to $18.8 \pm 1.5$ and $25.5 \pm 2,1 \mathrm{ng} \mathrm{l}^{-1}$, respectively, while COD DIss in treatments without UV averaged $33.5 \mathrm{mg} \mathrm{l}^{-1}$.

Particulate COD largely reflected the development i. Pv (fig. $2 \mathrm{f}$ vs. $2 \mathrm{~b}$ ). This was supported by an overall correlation coefficient of 0.96 between the two parameters (table 2). Particulate COD was only slightly affected (no statistical

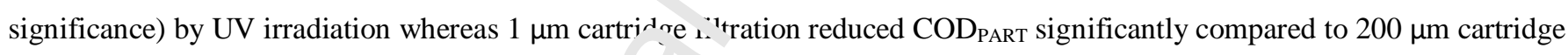
filtration (table 1 and fig. 2f). Particulate COD in tre ttr ent $200 \mu \mathrm{m} \div \mathrm{UV}$ rose steadily from the beginning of the trial to a final value of $20.7 \pm 6.6 \mathrm{mg} \mathrm{l}^{-1}$, followed by $200_{r} \mathrm{n}+\mathrm{JV}$ averaging $16.2 \pm 2.8 \mathrm{mg} \mathrm{l}^{-1}$. In comparison, treatments with $1 \mu \mathrm{m}$ cartridge filters ended at an average of $3.7 \pm \iota .7 \mathrm{mg} \mathrm{l}^{-1}$.

\section{Discussion}

\subsection{Cartridge filtration effects}

The use of $1 \mu \mathrm{m}$ compared to $20 \mathrm{C}_{\boldsymbol{1}} . \mathrm{n}$ cartridge filters resulted, as expected, in a significant removal of particles by volume $(\sim 83 \%)$ accompanied by a large reduction in $\operatorname{COD}_{\text {PART }}(\sim 80 \%)$. At the same time the microbial activity was reduced by approximately $50 \%$ in $1 \mu \mathrm{m}$ compared to $200 \mu \mathrm{m}$ filtered systems. However, due to the interaction between cartridge filters and UVs with respect to microbial activity, it's not possible to determine to what extent this result were caused by the cartridge filters. The reduction in microbial activity fits well with a removal of suspended solids serving both as microbial substrate and surface area for bacteria (Pedersen et al., 2017). Besides the removal of substrate, the cartridge filters may also have resulted in a direct removal of free-living bacteria from the water. Using membrane filtration, Wold et al. (2014) found that water treated with a $50 \mathrm{~nm}$ membrane filter contained $80 \%$ less bacteria than a control systems without filter, and that this was accompanied by increased growth and survival rate of cod larvae. In the current study, the reduction in microbial activity was less pronounced. This was probably a consequence of using $1 \mu \mathrm{m}$ vs. $50 \mathrm{~nm}$ membrane filters since $1 \mu \mathrm{m}$ filters may not remove all planktonic bacteria and colloidal particles. Additional explanations relate to different study setups and different methods of measuring bacteria / determining bacterial activity $\left(\mathrm{H}_{2} \mathrm{O}_{2}\right.$ degradation assay in the present study vs. flow cytometry in the study 
by Wold et al. (2014)). Micro filtration can reduce the load of bacteria in an aquaculture system either directly or indirectly. The reduction in most metrics in the current study significantly relating to cartridge filtration (i.e., PN, PV, PSA, and

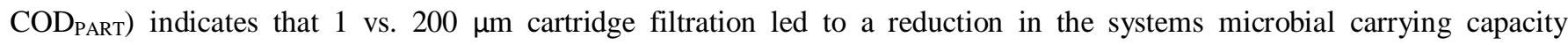
(Attramadal et al., 2012a; Skjermo et al., 1997). Systems are considered microbially stable when microbial activity is close to the maximum that the system can sustain based on the amount of substrate (organic matter) available. Bacterially stable systems have proven advantageous for breeding Atlantic halibut (Hippoglossus hippoglossus) and Atlantic cod (Gadus morhua) larvae (Attramadal et al., 2012a; Vadstein et al., 1993). Removal of particulate organic matter is also considered an advantage by, for example, reducing the scope for heterotrophic growth, as well as reducing the potential for deposition and clogging in the system.

The results obtained here indicate that the cartridge filters had both direct impacts (removal of free swimming bacteria and bacterial biofilm) and indirect impact by removing substrate for bacteria to grow or.

\subsection{Effects of UV irradiation}

The antimicrobial effect of UV irradiation is well documented (Emerick et il., . 999; Loge et al., 1999; Sharrer et al., 2005; Summerfelt, 2003; Timmons and Ebeling, 2010), while the impact of UV $\because$-adıaı on micro particles is less described.

UV treatment in the current study resulted in significantly fewer part cles in the water compared to equivalent RAS without UV (fig. 2a) as well as in a reduction in microbial activity (comparing vithin same cartridge filter pore size; fig. 2d). For example, $1 \mu \mathrm{m}+\mathrm{UV}$ treatment systems contained approximate $\mathrm{y}, \Delta \%$ fewer particles and $70 \%$ less PSA than $1 \mu \mathrm{m} \div \mathrm{UV}$ systems at the end of the trial. These reductions were acco: vanıu by $90 \%$ less microbial activity in $1 \mu \mathrm{m}+\mathrm{UV}$. Similar differences were observed between $200 \mu \mathrm{m}+\mathrm{UV}$ vs. $200 \mathrm{~m} \div \mathrm{UV}$ systems and sustains that UV reduces the number of particles presumably by killing bacteria.

A low HRT in system rearing tanks (approximately 26 ninutes) also reduced the likelihood of bacteria multiplying within the tanks when not exposed to UV disinfection. This is st pported by the results as samples were obtained just after the rearing units and before the UV disinfection, as well a ; the fact that bacteria activity in UV treated systems by the end of the trial was similar to that in the start of the trial.

Previous studies have shown that large amı 'nts of particles in the water reduces the efficiency of UV (Carre et al., 2018; Qualls et al., 1983). This was not the $\sim a^{\prime}$ in the current study, where microbial activity levels in both $1 \mu \mathrm{m}+\mathrm{UV}$ and $200 \mu \mathrm{m}+$ UV treated systems remained low the ‥ onout the experiment despite relatively high numbers of particles. This discrepancy may relate to the use of UV from the $s$ art of the trial. In previous aquaculture related studies evaluating UV efficiency, UV has typically been applied to water samples only after they contained high levels of bacteria. Under such conditions, bacteria in biofilms attached to particle surfaces are less exposed, and this may partly protect them from the effects of UV irradiation (Emerick et al., 1999; Loge et al., 1999). In the current study, bacteria where subjected to constant UV dosing from the very start which probably prevented them from forming large biofilm formations on particles. Furthermore, the applied UV dose was capable of delivering up to approximately $100 \mathrm{~mW}-\mathrm{s} \mathrm{cm}^{-2}$ (62\% UV transmission in the cleaner / less turbid tanks), and was thus over-dimensioned for the systems. Commercial facilities generally use UV systems producing only $30-35 \mathrm{~mW}-\mathrm{s} \mathrm{cm}^{-2}$ (Lekang, 2007). While the dose applied in the current study was high, it was still within the range applied by Sharrer et al. (2005) using doses of up to $1800 \mathrm{~mW}-\mathrm{s} \mathrm{cm}^{-2}$ in pilot-scale RAS, and obtaining up to $98 \%$ reduction in heterotrophic bacteria counts. In that same study, a $300 \mathrm{~mW}-\mathrm{s} \mathrm{cm}^{-2}$ dose resulted in an $81 \%$ reduction in total heterotrophic bacteria counts. This is quite similar to the reduction obtained in the current study (approximately 88\% reduction when comparing within the same cartridge filter pore size) although direct comparisons are hampered by different bacteria measuring techniques. All together, 
the results sustain that the reduction in micro particles in systems treated with UV is mainly due to a reduction in bacteria. This hypothesis is further reinforced by the fact that the reduction in particle numbers and surface area mainly happened in the smallest size fraction, as seen from significantly smaller $\beta$ values in UV treated systems indicating that the particle size distribution changed towards relatively larger particles (Patterson et al., 1999).

A further effect of UV was a reduction in both COD fractions (although only statistically significant on dissolved COD). While a reduction in particulate COD was anticipated as an effect of finer mesh cartridge filtration, a reduction in the particulate and especially in the dissolved COD fraction in UV treated systems was less expected. Microbial organic matter (organic matter which makes up the body of bacteria) constitutes part of CODPART and therefore a reduction in bacterial numbers will also eventually reduce COD PART. UV should on the other end have no direct impact on dissolved COD and we speculate whether the reduction relates to a lower microbial activity. Keeping bacterial activity in the water at a low level might result in a slower degradation of particulate matter and thereby, a slower transition of organic matter from the particulate to the dissolved fraction (Henze et al., 1997). The positive correlation between microbial activity anı TOD supports this explanation (table 2). It is also likely that part of the COD was consumed and thus stored inside the iofil $2 r$ due to reduced competition from free swimming bacteria making more organic matter available to bacteria in $1 \mathrm{e} \iota$ ofilm. A slower degradation of particulate organic matter may additionally resulted in a positive feedback in a RAS yy 11ureasing the efficiency of mechanical removal devices, which could help to explain the differences in particle number, see 7 between treatments. However, further research is needed to resolve this, including an assessment of the organic mattor - moved, as well as an assessment of the biofilter condition over the course of the trial.

The reduction in most measured parameters caused by UV irr diauvil, including especially the reduction in CODDIss, suggests that much like cartridge filtration, UV lead to a reducti $\mathrm{n}$ ir system carrying capacity. However, while UV may have led to a reduction in the system carrying capacity of the water by + ducing easily available organic matter in the water phase, it also selectively eliminated bacteria from the water phase, otentially pushing the microbiota below the carrying capacity of the systems and causing a shift in bacterial commu. it es While such changes in bacterial communities were shown to have negative effects on cod larvae (Attramadal et $a ., \iota^{1} 2 \mathrm{~b}$ ), similar effects on rainbow trout remain to be studied.

Hence, while a reduced microbial activity ind ıss particulate matter may generally be perceived as positive, it could be hazardous in case of UV failure suddenly t. $\cdot \mathrm{k}$ kng a part of the system carrying capacity available for fast growing bacteria. The balance between UV irradiation .... n nucrobial carrying capacity is thus important considering potential effects of a UV failure.

As discussed in the introduction, part of the total micro particles in RAS is composed of bacteria. The results obtained by the use of intensive UV reducing PN by approximately $84 \%$ suggest that, at least by numbers, the proportion of bacteria in the very small fraction of micro particles is very high in intensive RAS, since the dose of UV applied should only affect the living cells.

\subsection{Combined effects}

The combination of UV treatment and microfiltration had synergistic effect on microbial activity. The combined effects of UV and cartridge filtration were probably a result of direct, mechanical bacteria removal and removal of substrate, as well as inactivation of bacteria due to UV exposure.

A combination of UV and $1 \mu \mathrm{m}$ cartridge filtration produced the best results including approximately $88 \%$ removal in all micro

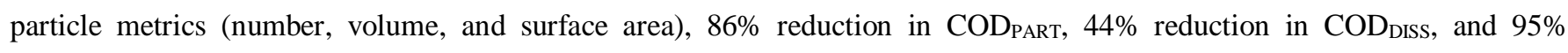
reduction in microbial activity. These results not only suggest a large reduction in the microbial carrying capacity, but 
potentially also a reduction in system oxygen consumption and $\mathrm{CO}_{2}$ accumulation. In addition, a large reduction in particulate matter could potentially reduce the risk of clogging and sludge deposition in the RAS loop.

\subsection{General system performance}

Fish mortality did not differ between treatment groups and were presumably primarily related to the relatively high temperatures (up to $22{ }^{\circ} \mathrm{C}$ ) experienced during the trial. Similarly, nitrate levels did not vary across treatments sustaining that all systems were operated at similar recirculation intensity, and also that the use of UV and cartridge filtration had no impact on the accumulation of nitrate.

\section{Conclusion}

Overall, this study showed that the use of either UV treatment or $1 \mu \mathrm{m}$ cartridge filtration significantly improved the water quality in pilot-scale RAS, with reductions across all measured water quality metrı $\varsigma$. The use of $1 \mu \mathrm{m}$ cartridge filtration especially reduced the amount of particulate organic matter, while UV treatmen led o a large reduction in microbial activity and micro particle numbers. Furthermore, the use of UV reduced the ar oun , of dissolved COD, suggesting a potential feedback mechanism between microbial activity and the amount of disso' 'ed organic matter in a system. The results suggest that $1 \mu \mathrm{m}$ filtration controlled the amount of micro particles and bacteı a by direct removal thereof, but also by the removal of substrate used by bacteria. In comparison, UV appears to reduce the d vee nment of micro particles trough the inactivation of bacteria in the water and in addition, by potentially reducing the va ic bility of dissolved substrate for microbial growth.

The use of $1 \mu \mathrm{m}$ cartridge filtration is, however, not realist. in most commercial applications where other techniques and technologies must be applied / developed if similar m: ro article removal is to be achieved. While UV may not be the first choice for addressing micro particle removal in RAS, the $\mu$ ssitive impact of the applied UV dose on micro particle levels, dissolved organic matter concentrations, and micrnhial ctivity in conjunction with their availability and ease of use, makes UV in combination with fine mechanical filtration a re nising tool for managing and improving water quality in RAS.

\section{Acknowledgement}

The study was partly funded by the Furop an Maritime and Fisheries Fund (EMFF) and the Danish Ministry of Food, Agriculture and Fisheries as part of r oje + "Vet-løsninger" (J.no. 33111-I-16-029).

Thanks to Ole Larsen and Rasmus 'elıs for all their help taking care of the fish and systems, and to Ulla Sproegel, Brian Moeller and Melissa Lyng for all th a $i$ assistance with the lab work.

\section{References}

Attramadal, K.J.K., Salvesen, I., Xue, R., Øie, G., Størseth, T.R., Vadstein, O., Olsen, Y., 2012a. Recirculation as a possible microbial control strategy in the production of marine larvae. Aquac. Eng. 46, 27-39.

doi:10.1016/j.aquaeng.2011.10.003

Attramadal, K.J.K., Øie, G., Størseth, T.R., Alver, M.O., Vadstein, O., Olsen, Y., 2012b. The effects of moderate ozonation or high intensity UV-irradiation on the microbial environment in RAS for marine larvae. Aquaculture 330-333, 121-129. doi:10.1016/j.aquaculture.2011.11.042

Becke, C., Schumann, M., Steinhagen, D., Geist, J., Brinker, A., 2018. Physiological consequences of chronic exposure of rainbow trout ( Oncorhynchus mykiss ) to suspended solid load in recirculating aquaculture systems. Aquaculture 484, 228-241. doi:10.1016/j.aquaculture.2017.11.030 
Brinker, A., 2007. Guar gum in rainbow trout (Oncorhynchus mykiss) feed: The influence of quality and dose on stabilisation of faecal solids. Aquaculture 267, 315-327. doi:10.1016/j.aquaculture.2007.02.037

Carré, E., Pérot, J., Jauzein, V., Lopez-Ferber, M., 2018. Impact of suspended particles on UV disinfection of activated-sludge effluent with the aim of reclamation. J. Water Process Eng. 22, 87-93. doi:10.1016/j.jwpe.2018.01.016

de Jesus Gregersen, K.J., Pedersen, P.B., Pedersen, L.-F., Dalsgaard, J., 2018. Micro particles and microbial activity in Danish recirculating rainbow trout (Oncorhynchus mykiss) farms. Aquac. Eng. doi:10.1016/j.aquaeng.2018.12.001

Emerick, R.W., Loge, F.J., Thompson, D., Darby, J.L., 1999. Factors Influencing Ultraviolet Disinfection Performance Part II: Association of Coliform Bacteria with Wastewater Particles. Water Environ. Res. 71, 1178-1187. doi:10.2175/106143097X122004

Fernandes, P.M., Pedersen, L.F., Pedersen, P.B., 2014. Daily micro particle distribution of an experimental recirculating aquaculture system-A case study. Aquac. Eng. 60, 28-34. doi:10.1016/j.aquaeng.2014.03.007

Fernandes, P.M., Pedersen, L.-F., Pedersen, P.B., 2016. Influence of fixed and movin dynamics in a recirculating aquaculture system. Aquac. Eng. doi:10.1016/j tquaı ng.2016.09.002

Franco-Nava, M.-A., Blancheton, J.-P., Deviller, G., Le-Gall, J.-Y., 2004. Pa acu 'te matter dynamics and transformations in a recirculating aquaculture system: application of stable isotope tracer in stavass rearing. Aquac. Eng. 31, $135-155$. doi:10.1016/j.aquaeng.2004.01.003

Henze, M., Harremoes, P., Arvin, E., Jansen, J. la C., 1997. Wasterwat॰r • eatment, 2nd editio. ed. Springer-Verlag Berlin Heidelberg, New York. doi:10.1007/978-3-662-22605-6

Huyben, D., Bevan, D., Stevenson, R., Zhou, H., Moccia, R., ? )18. Evaluation of membrane filtration and UV irradiation to control bacterial loads in recirculation aquaculturf syst ms. Aquac. Int. 26, 1531-1540. doi:10.1007/s10499-018-0301-z

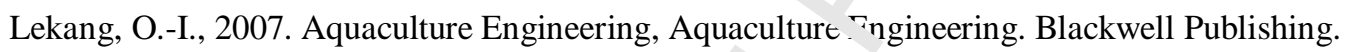

Loge, F.J., Emerick, R.W., Thompson, D.E., Nelson, L. C., Darby, J.L., 1999. Factors Influencing Ultraviolet Disinfection Performance Part I: Light Penetration to Wa te va _r Particles. Water Environ. Res. 71, 377-381. doi:10.2175/106143097X122176

Lu, C., Kania, P.W., Buchmann, K., 2018. F· rticlu effects on fish gills: An immunogenetic approach for rainbow trout and zebrafish. Aquaculture 484, 98-104. al $: 10.1016 /$ j.aquaculture.2017.11.005

Patterson, R.N., Watts, K.C., Timmor s, M.ь., 1999. The power law in particle size analysis for aquacultural facilities. Aquac.

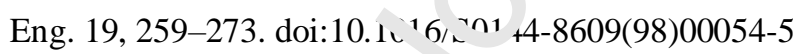

Pedersen, P.B., von Ahnen, M., Ferna' des, P.M., Naas, C., Pedersen, L.-F., Dalsgaard, J., 2017. Particle surface area and bacterial activity in recirculating aquaculture systems. Aquac. Eng.

Pedersen, L.F., Rojas-Tirado, P., Arvin, E., Pedersen, P.B., 2019. Assessment of microbial activity in water based on hydrogen peroxide decomposition rates. Aquac. Eng. 85, 9-14. doi:10.1016/j.aquaeng.2019.01.001

Qualls, R.G., Flynn, M.P., JR, J.M.C., 1983. The role of suspended particles in ultraviolet disinfection. J. Water Pollut. Control Fed. 55, 1280-1285. doi:10.2307/25042084

Schumann, M., Unger, J., Brinker, A., 2017. Floating faeces: Effects on solid removal and particle size distribution in RAS. Aquac. Eng. 78, 75-84. doi:10.1016/j.aquaeng.2016.10.007

Sharrer, M.J., Summerfelt, S.T., Bullock, G.L., Gleason, L.E., Taeuber, J., 2005. Inactivation of bacteria using ultraviolet irradiation in a recirculating salmonid culture system. Aquac. Eng. 33, 135-149. doi:10.1016/j.aquaeng.2004.12.001

Skjermo, J., Saivesen, I., Øie, G., Olsen, Y., Vadstein, O., 1997. Microbially matured water : a technique for selection of a non-opportunistic bacterial flora in water that may improve performance of marine larvae. Aquac. Int. 5, $13-28$. 


\section{doi:10.1007/BF02764784}

Summerfelt, S.T., 2003. Ozonation and UV irradiation. Aquac. Eng. 28, 36.

Timmons, M.B., Ebeling, J.M., 2010. Recirculating Aquaculture, 2nd ed. Cayuga Aqua Ventures, NY, USA.

Unger, J., Brinker, A., 2013. Floating feces: A new approach for efficient removal of solids in aquacultural management. Aquaculture 404-405, 85-94. doi:10.1016/j.aquaculture.2013.04.015

Vadstein, O., Øie, G., Salvesen, I., Skjermo, J., 1993. A strategy to obtain microbial control during larval development of marine fish. Fish Farming Technol. 69-75.

Viadero, R.C., Noblet, J.A., 2002. Membrane filtration for removal of fine solids from aquaculture process water. Aquac. Eng. 26, 151-169. doi:10.1016/S0144-8609(02)00011-0

Wold, P.-A., Holan, A.B., Øie, G., Attramadal, K., Bakke, I., Vadstein, O., Leiknes, T.O., 2014. Effects of membrane filtration on bacterial number and microbial diversity in marine recirculating aquaculture system (RAS) for Atlantic cod (Gadus morhua L.) production. Aquaculture 422-423, 69-77. doi:10.1016/j.aquaculture. 013.11 .019

Wu, J., Le-Clech, P., Stuetz, R.M., Fane, A.G., Chen, V., 2008. Effects of relaxa on a d backwashing conditions on fouling in membrane bioreactor. J. Memb. Sci. 324, 26-32. doi:10.1016/j.memsci 20u? 06.057 
Table 1. Two-way analysis of variance (Anova) of particle data carried out on data from the end of the trial.

\begin{tabular}{|c|c|c|c|c|c|c|c|}
\hline Treatment & $\begin{array}{l}\text { Statistical } \\
\text { parameter }\end{array}$ & $\begin{array}{l}\text { Particle } \\
\text { Number } \\
\left(\# \mathrm{ml}^{-1}\right)\end{array}$ & $\begin{array}{c}\text { Particle } \\
\text { Volume } \\
\left(\mathrm{mm}^{3} \mathrm{ml}^{-1}\right)\end{array}$ & $\begin{array}{c}\text { Particle } \\
\text { Surface Area } \\
\left(\mathrm{mm}^{2} \mathrm{ml}^{-1}\right)\end{array}$ & $\begin{array}{c}\text { Microbial } \\
\text { activity } \\
\left(\mathrm{k}^{-1}\right)\end{array}$ & $\begin{array}{c}\text { COD DISS } \\
\left(\mathrm{mg} \mathrm{l}^{-1}\right)\end{array}$ & $\begin{array}{c}\text { COD }_{\text {PART }} \\
\left(\mathrm{mg} \mathrm{l}^{-1}\right)\end{array}$ \\
\hline \multirow[t]{2}{*}{ Within UV } & $\mathrm{F}$ & 37.4 & 2.8 & 19.8 & 66.8 & 42.0 & 1.3 \\
\hline & p-value & $<0.001$ & 0.130 & 0.002 & $<0.001$ & $<0.001$ & 0.281 \\
\hline \multirow[t]{2}{*}{ Within Filter } & $\mathrm{F}$ & 7.5 & 46.8 & 65.0 & 13.0 & 4.1 & 32.2 \\
\hline & $\mathrm{p}$-value & 0.025 & $<0.001$ & $<0.001$ & 0.007 & 0.078 & $<0.001$ \\
\hline \multirow[t]{2}{*}{ Interaction } & $\mathrm{F}$ & 0.08 & 1.6 & 0.89 & 7.7 & 2.2 & 0.4 \\
\hline & p-value & 0.782 & 0.237 & 0.372 & 0.024 & 0.173 & 0.566 \\
\hline
\end{tabular}


Table 2. Pearson's correlation coefficients (r) between selected water quality parameters measured throughout the trial.

\begin{tabular}{|c|c|c|c|c|c|c|}
\hline Comparison & $\begin{array}{l}\text { Statistical } \\
\text { parameter }\end{array}$ & $\begin{array}{c}1 \mu \mathrm{m} \div \mathrm{UV} \\
(\mathrm{n}=12)\end{array}$ & $\begin{array}{c}200 \mu \mathrm{m} \div \mathrm{UV} \\
(\mathrm{n}=12)\end{array}$ & $\begin{array}{c}1 \mu \mathrm{m}+\mathrm{UV} \\
(\mathrm{n}=12)\end{array}$ & $\begin{array}{c}200 \mu \mathrm{m}+\mathrm{UV} \\
(\mathrm{n}=12)\end{array}$ & $\begin{array}{c}\text { Total data* } \\
\quad(\mathrm{n}=48)\end{array}$ \\
\hline \multirow{2}{*}{$\begin{array}{c}\text { Volume of particles vs } \\
\text { CODPART }\end{array}$} & $\mathrm{r}$ & 0.98 & 0.96 & 0.97 & 0.96 & 0.96 \\
\hline & $\mathrm{p}$ & $<0.001$ & $<0.001$ & $<0.001$ & $<0.001$ & $<0.001$ \\
\hline \multirow{2}{*}{$\begin{array}{c}\text { Microbial activity vs } \\
\text { COD DISS }\end{array}$} & $\mathrm{r}$ & 0.66 & 0.81 & 0.78 & 0.61 & 0.78 \\
\hline & $\mathrm{p}$ & 0.018 & 0.0013 & 0.0026 & 0.0367 & $<0.001$ \\
\hline \multirow{2}{*}{$\begin{array}{c}\text { Microbial activity vs } \\
\text { COD }_{\text {TOTAL }}\end{array}$} & $\mathrm{r}$ & 0.65 & 0.79 & 0.83 & 0.76 & 0.79 \\
\hline & $\mathrm{p}$ & 0.02 & 0.002 & $<0.001$ & 0.003 & $<0.001$ \\
\hline \multirow{2}{*}{$\begin{array}{l}\text { Microbial activity vs } \\
\text { Number of particles }\end{array}$} & $\mathrm{r}$ & 0.93 & 0.95 & 0.93 & 0.87 & 0.95 \\
\hline & $\mathrm{p}$ & $<0.001$ & $<0.001$ & $<0.6 u^{\overline{1}}$ & $<0.001$ & $<0.001$ \\
\hline
\end{tabular}

*Total data corresponds to correlations made with all data points from the $4 \mathrm{c}$.tte 'nt treatments. 

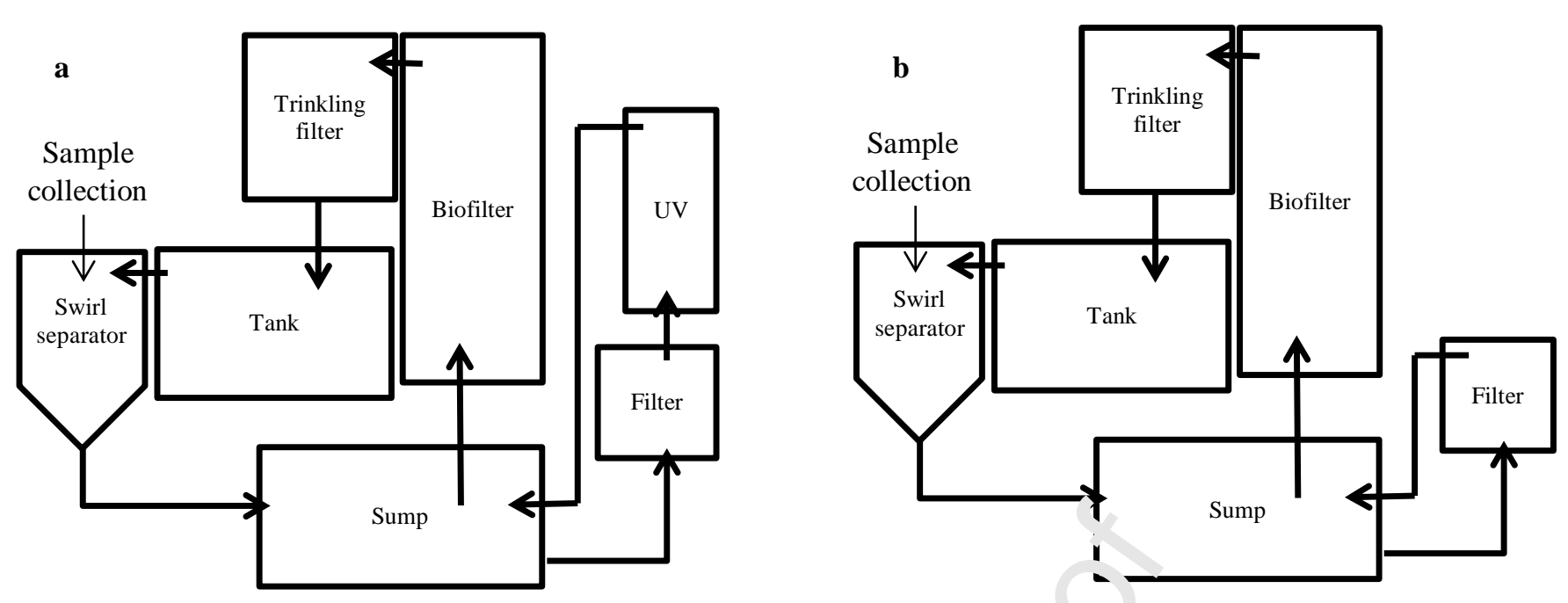

Figure 1: Simplified schematic representation of the 12 RAS units used in + 1 e trial, depicting the sampling location and components and filtration units added: a) System fitted with filter housi $1 \mathrm{~g}$ a. $\mathrm{d}$ UV; b) System fitted only with filter housing. Within each UV treatment (i.e., UV or no UV) filter housings were fiı 1 with wither a $1 \mu \mathrm{m}$ or a $200 \mu \mathrm{m}$ cartage filters. Arrows indicate the direction of the flow. 


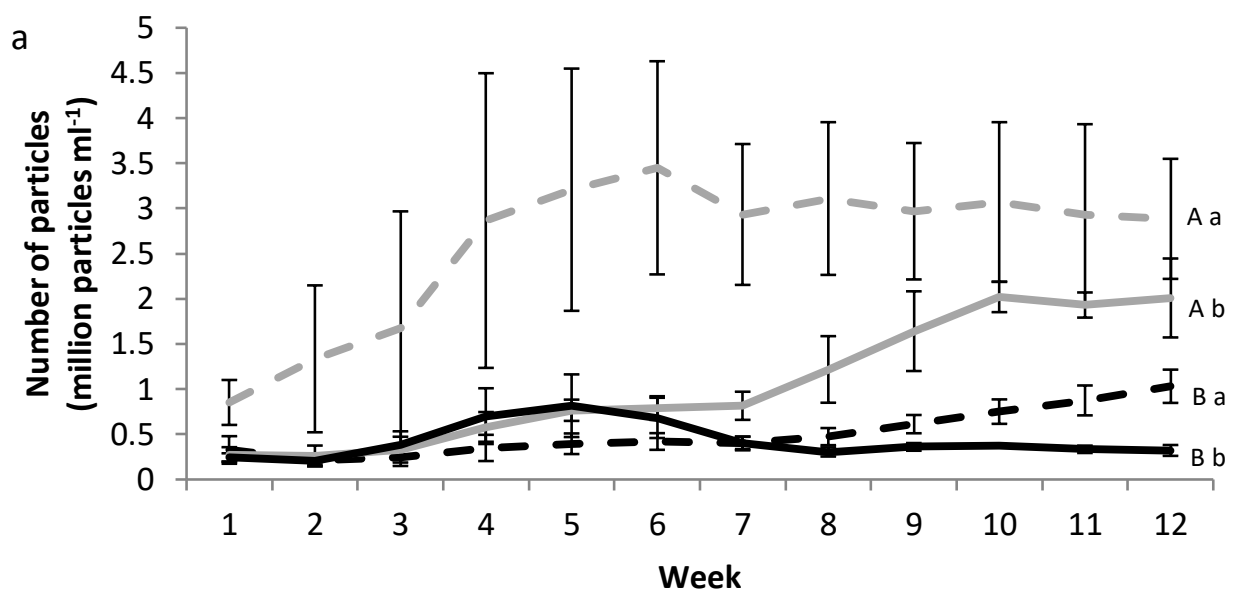

$-200 \mu m \div U V--200 \mu m+U V$ $1 \mu \mathrm{m} \div \mathrm{UV}$ $1 \mu \mathrm{m}+U_{v}$

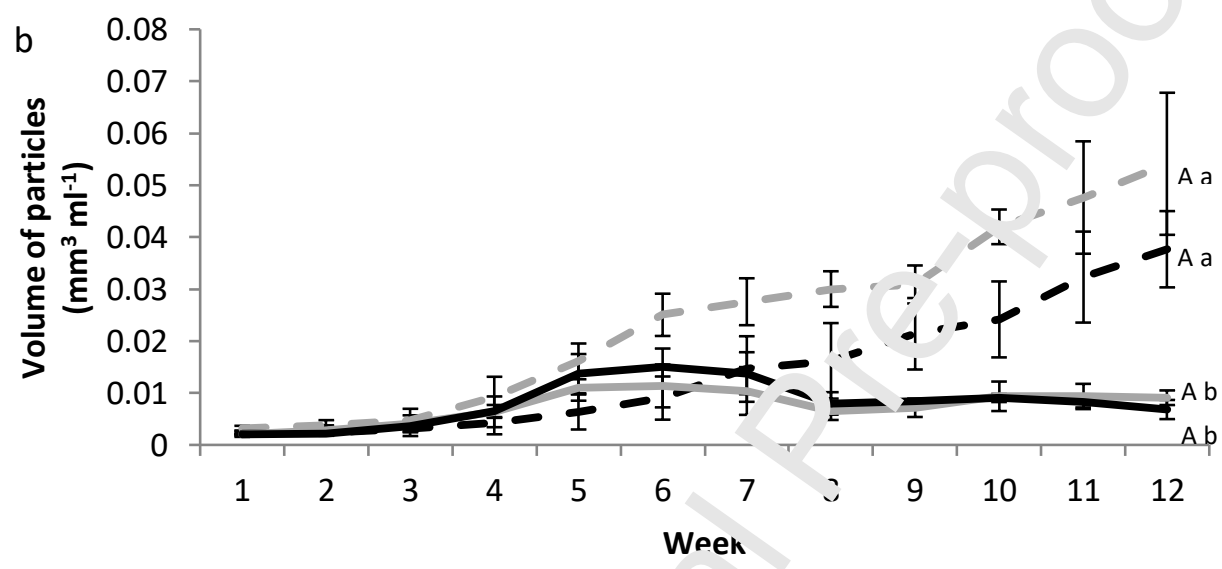

$-200 \mu \mathrm{m} \div \mathrm{UV}--200 \mu \mathrm{m}+\mathrm{UV}^{\prime}-1 \mu \mathrm{m} \div \mathrm{UV}-1 \mu \mathrm{m}+\mathrm{UV}$

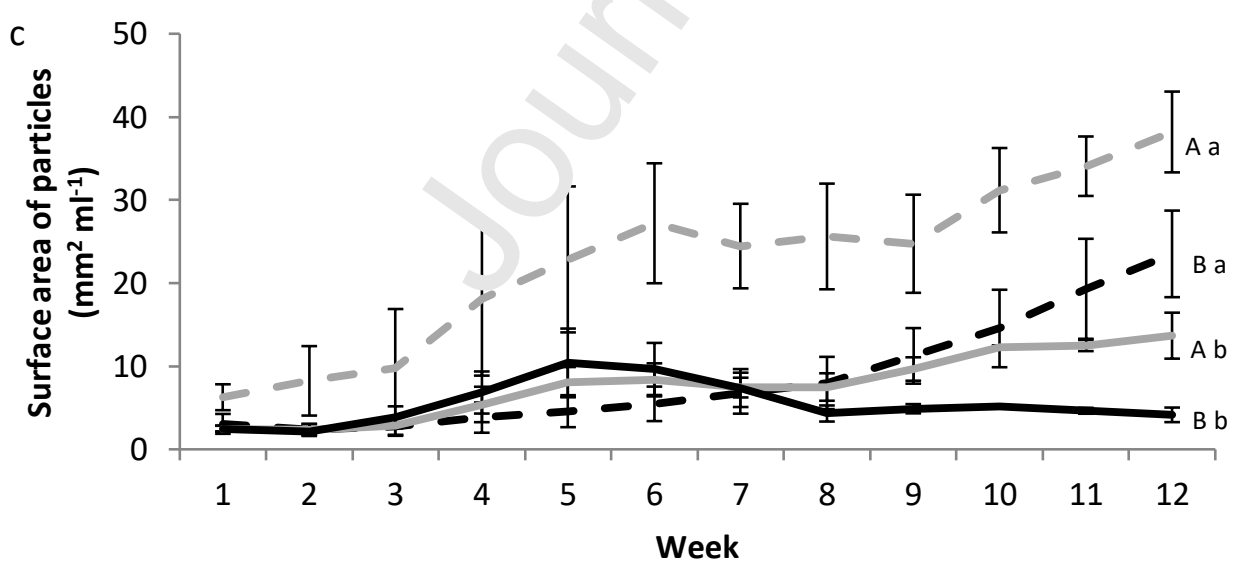

$-200 \mu m \div U V--200 \mu m+U V \longrightarrow 1 \mu m \div U V \longrightarrow$ UV 


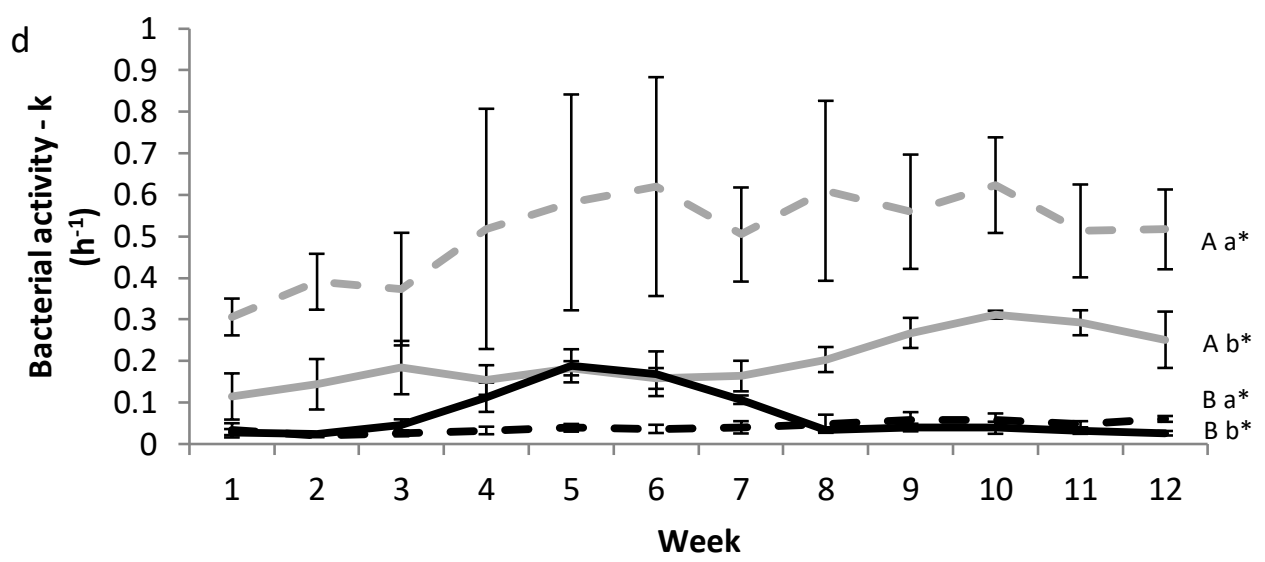

$-200 \mu \mathrm{m} \div \mathrm{UV}-200 \mu \mathrm{m}+\mathrm{UV} \longrightarrow 1 \mu \mathrm{m} \div \mathrm{UV} \longrightarrow 1 \mu \mathrm{m}$ ' 'JV

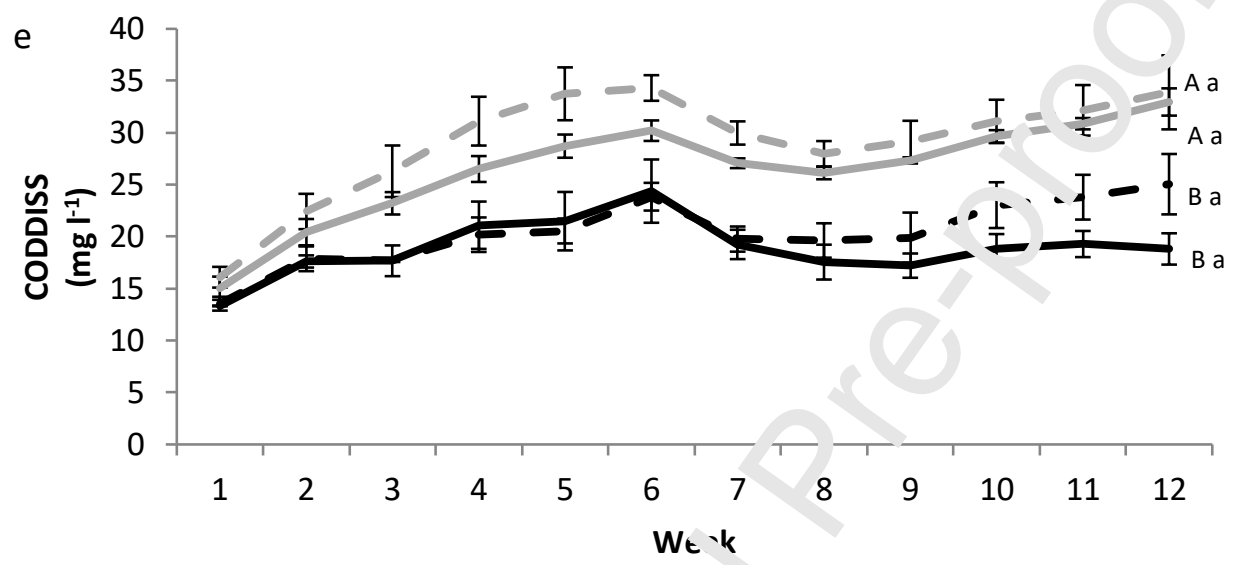

$-200 \mu \mathrm{m} \div \mathrm{UV}--200 \mu \mathrm{m}+\mathrm{UV}=-1 \mu \mathrm{m} \div \mathrm{UV}-1 \mu \mathrm{m}+\mathrm{UV}$

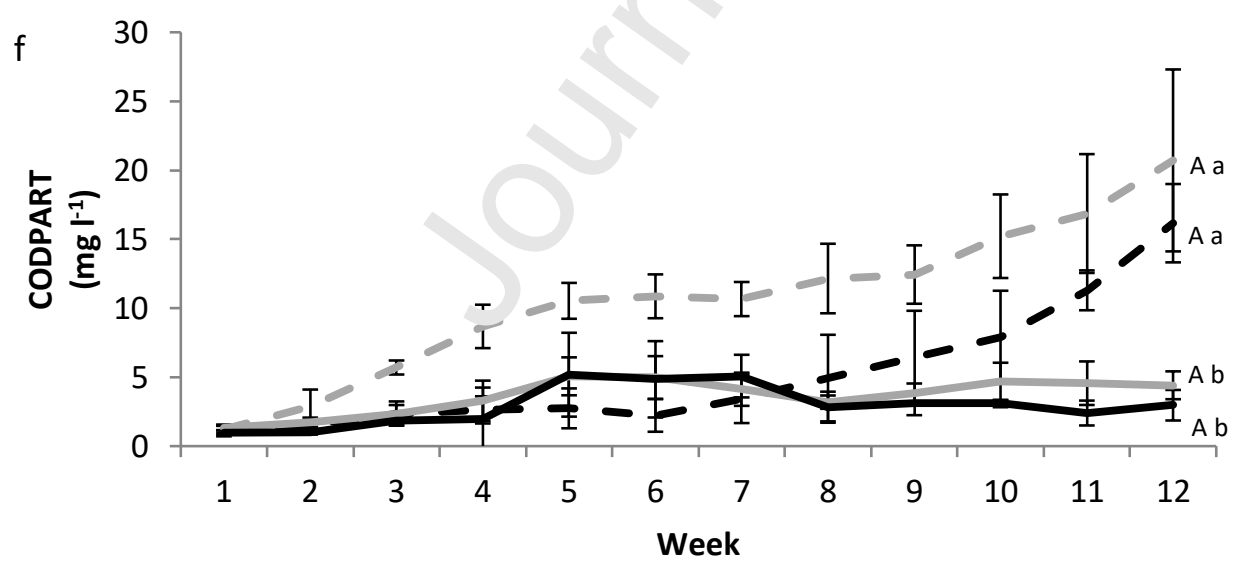

$-200 \mu \mathrm{m} \div \mathrm{UV}--200 \mu \mathrm{m}+\mathrm{UV} \longrightarrow 1 \mu \mathrm{m} \div \mathrm{UV}-1 \mu \mathrm{m}+\mathrm{UV}$ 
Figure 2: Time series of measured water quality parameters during the trial. Results are shown as moving average of 3 data points. Statistical differences at the end of the trial are indicated in the figure and summarized in table 1. Different capital letters indicate differences within UV treatment while different small letter indicate differences within cartridge filtration treatments. a) Number of particles b) Volume of particles c) Surface area of particles d) Microbial activity e) COD particulate f) COD dissolved. *Interactions between main factors (UV and filters), in which case statistics refers to the difference within each main factor. 
The work presented in this manuscript provides clear indication of the potential for particulate matter control by both micro filters but more importantly, by ultraviolet radiation.

The study illustrates the clear and complex interactions between bacteria and organic matter in recirculation aquaculture systems.

The influence of bacteria in the total amount of particulate matter in recirculation aquaculture systems can be seen for the first time in replicated setups, indicating that large proportions of what is generally called particulate matter is in fact composed of live organisms.

The results obtained provide new insights in to the development of particulate matter in recirculation aquaculture systems, which could lead to the development of new technics to control particulate matter. 


\section{Declaration of interests}

$\bigotimes$ The authors declare that they have no known competing financial interests or personal relationships that could have appeared to influence the work reported in this paper.

$\square$ The authors declare the following financial interests/personal relationships which may be considered as potential competing interests: 


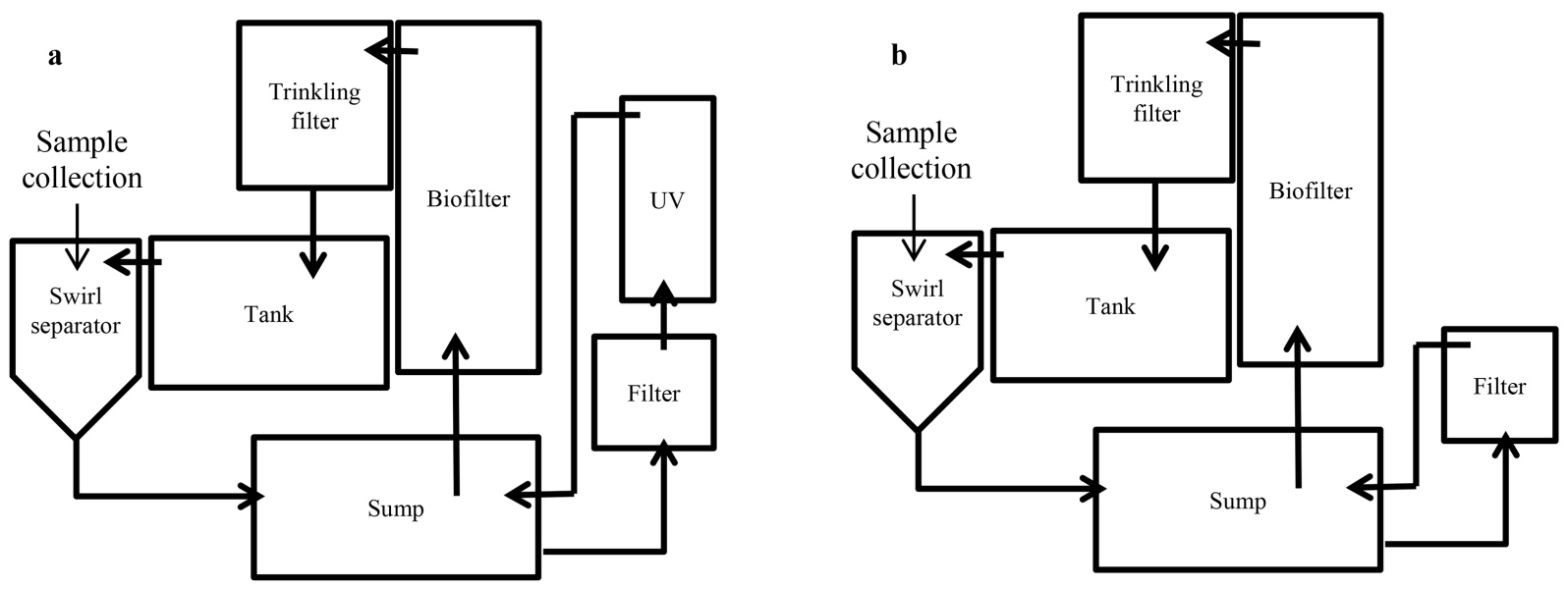

Figure 1 


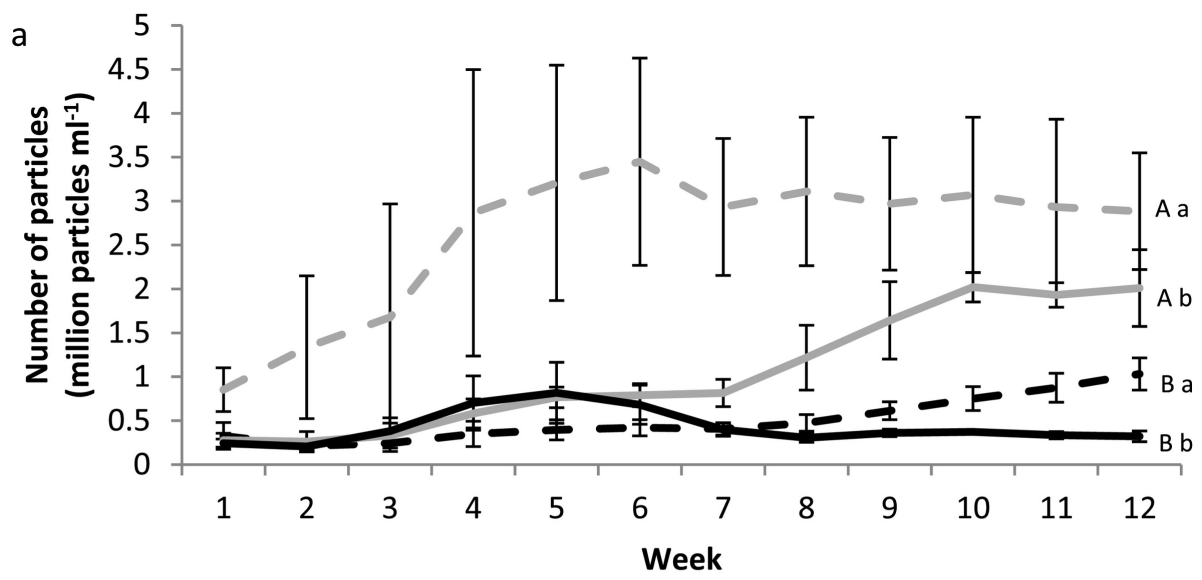

$-200 \mu \mathrm{m} \div \mathrm{UV}--200 \mu \mathrm{m}+\mathrm{UV}-1 \mu \mathrm{m} \div \mathrm{UV}-1 \mu \mathrm{m}+\mathrm{UV}$

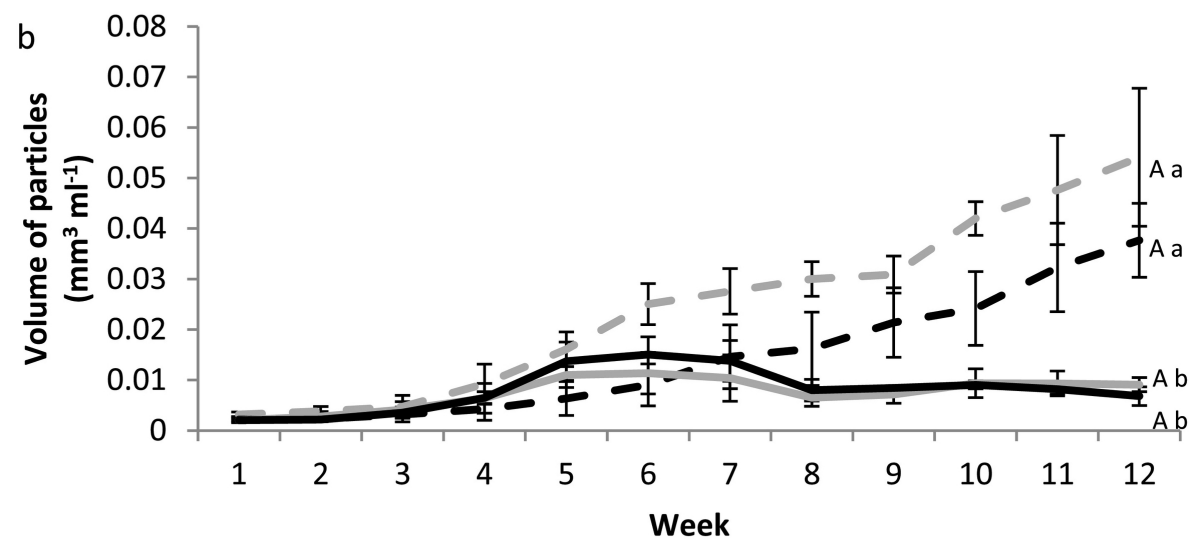

$-200 \mu \mathrm{m} \div \mathrm{UV}--200 \mu \mathrm{m}+\mathrm{UV}-1 \mu \mathrm{m} \div \mathrm{UV}-1 \mu \mathrm{m}+\mathrm{UV}$

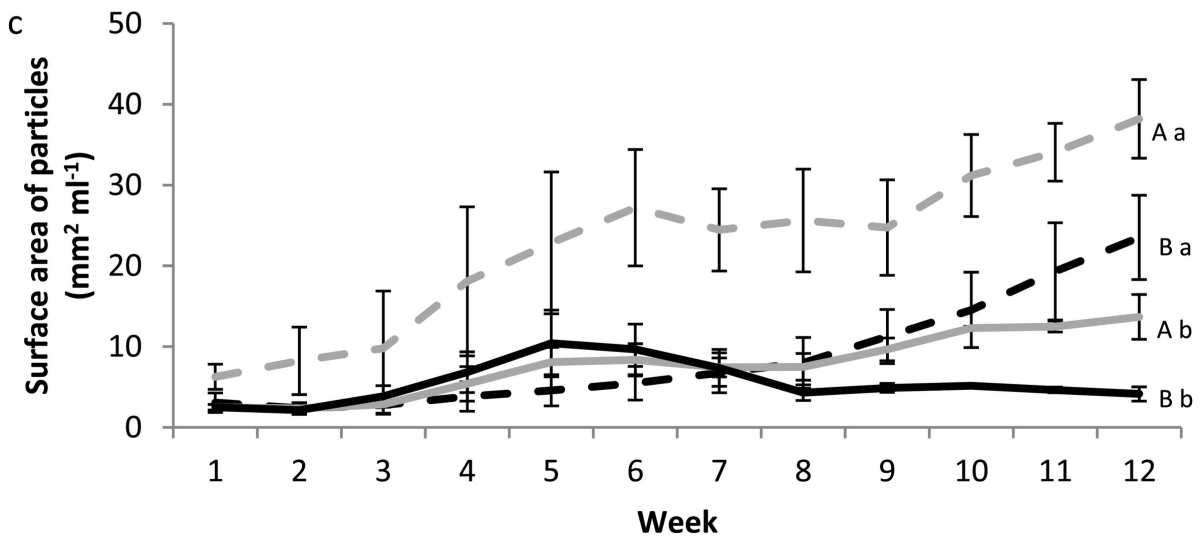




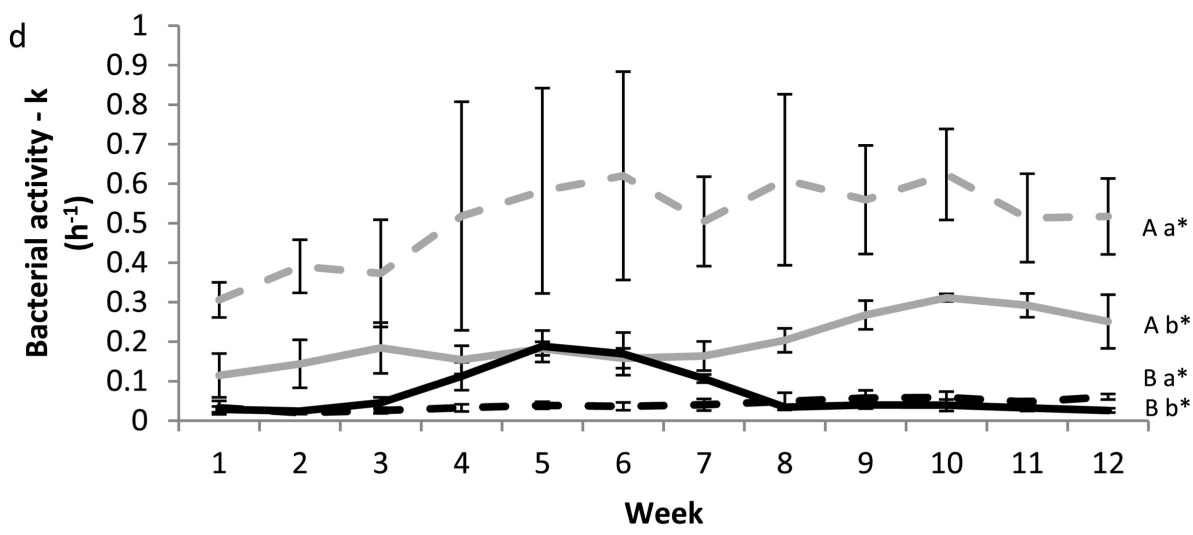

$-200 \mu \mathrm{m} \div \mathrm{UV}-200 \mu \mathrm{m}+\mathrm{UV} \longrightarrow 1 \mu \mathrm{m} \div \mathrm{UV} \longrightarrow 1 \mu \mathrm{m}+\mathrm{UV}$

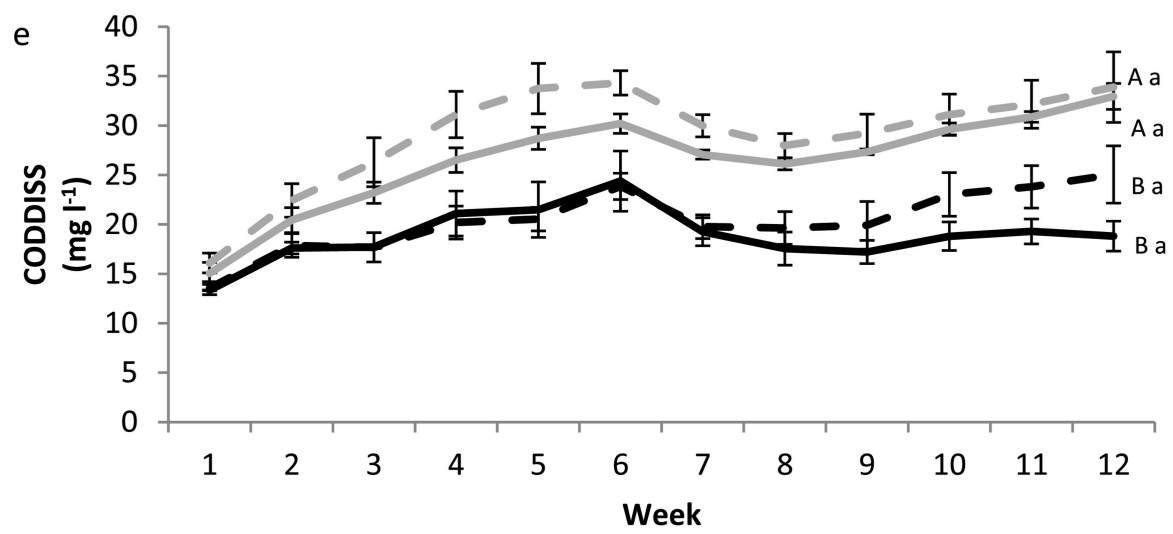

$-200 \mu \mathrm{m} \div \mathrm{UV}--200 \mu \mathrm{m}+\mathrm{UV}-1 \mu \mathrm{m} \div \mathrm{UV}-1 \mu \mathrm{m}+\mathrm{UV}$

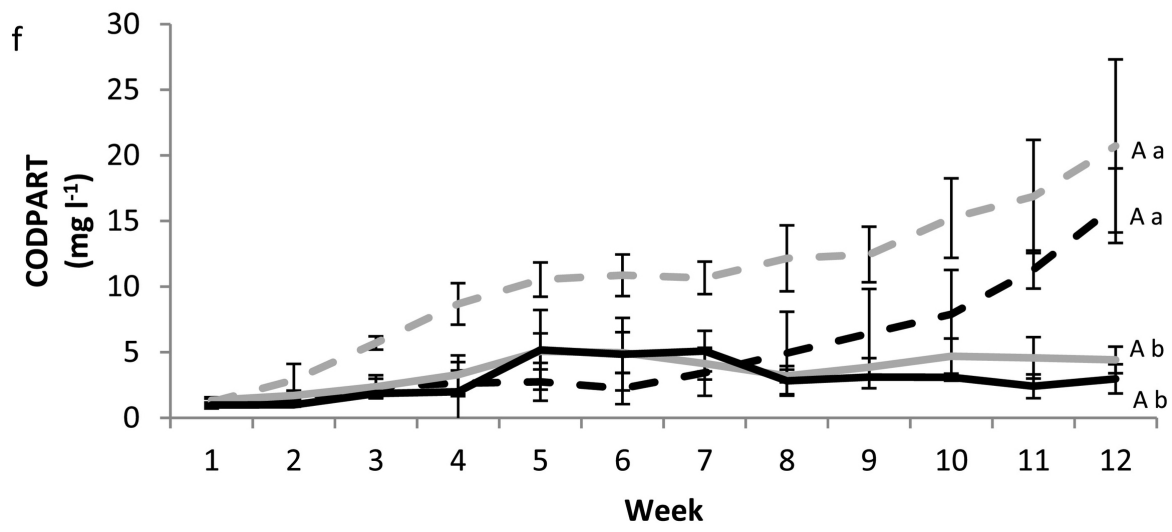

